\title{
Hellenistic and Roman Steles in the Museum of Tarsus in Cilicia
}

\author{
Ergün LAFLI* - Eva CHRISTOF**
}

Greek and Roman steles for funerary or commemorative purposes from Asia Minor were investigated mostly by German scholars, such as Ernst Pfuhl, Hans Möbius, Johanna Fabricius, Stefan Schmidt, Reinhold Merkelbach and Josef Stauber. ${ }^{1}$ The legendary publication of Pfuhl and Möbius offers a firm base, but Cilicia is not very well represented in this book. ${ }^{2}$ It seems that Cilicia (map 1) is not rich in terms of Greek and Roman steles and this type of commemoration was not very popular. Previous archaeological excavations in necropoleis of Cilicia, such as Anemurium, ${ }^{3}$ Elaeousa-Sebaste, Kelenderis, Nagidus, Soloi-Pompeiopolis or Tarsus, reported very few steles. Except the European travellers of the $19^{\text {th }}$ cent. Robert Fleischer was the first fellow who presented the sculptural richness of Roman Cilicia. ${ }^{4}$ The dissertation of Ayşe Çalık Ross on the Roman Imperial sculpture of Cilicia in 1997 includes the pieces in the Museum of Tarsus, ${ }^{5}$ but not the steles. With this article we begin a series of research papers, concerning the Greek and Roman steles from Cilicia, especially those kept in the local museums, such as Tarsus, Adana and Alanya. In this series of articles we plan to deal with

* Prof. Dr. Ergün Laflı, Dokuz Eylül Üniversitesi, Edebiyat Fakültesi, Arkeoloji Bölümü, A-418, Tinaztepe/Kaynaklar Yerleşkesi, Buca, 35160 İzmir (elafli@yahoo.ca).

** Mag. Dr. Eva Christof, c/o Institut für Archäologie der Karl-Franzens-Universität Graz, Universitätsplatz 3/2, A-8010Graz (eva.christof@uni-graz.at).

Abbreviations (alphabetically): Cent.: century; esp.: especially; fig.: figure; h.: height; h. o. ltr.: height of letters; inv. no.: inventory number; p.: preserved; and w.: width. For the study of these objects at the Museum of Tarsus four authorizations were issued by the Turkish General Directorate of the Cultural Heritage and Museums on 04/07/2007, numbered as B.16.0.KVM.200.11.02.02.14.01.222.11.(TA07.40/C), on 04/07/2007, numbered as B.16.0.KVM.200.11.02.02.14.01.222.11.(TA07.40/E), on 10/06/2005, numbered as B.16.0.KVMG.0. 10.00.01/707.1.(9)-80021 and on 09/12/2004, numbered as B.16.0.KVMG.0.10.00.01/707.1/14-030314. The documentation has been done in 2006 and on 01/03/2013. Photos nos. 1-3b, 5 and 7-10 were taken by Peter Grunwald (Berlin) in 2006 and nos. 4 as well as 6 by Dr Gülseren Kan Şahin (Sinop) in 2013.

The authors wish to thank to Prof. Nalân Eda Akyürek Şahin, the editor of Gephyra, for her kind invitation to prepare this brief paper. We would also like to thank to Dr. Ilias N. Arnaoutoglou (Athens) and Prof. Dr. Johannes Nollé (Munich) for their revisions of our text epigraphically. In our excursions in 2006 Dr. Jutta Meischner (Berlin) was also present to whom we would like to thank for her support. This article has been dedicated to the good memory of Professor Sencer Şahin $(\dagger)$ who was always a strong supporter of young researchers.

${ }^{1}$ PM 1-2; Fabricius 1999; Schmidt 1991; and Merkelbach - Stauber 2002.

${ }^{2}$ For instance a Hellenistic stele with a little girl with a soft curly hairstyle from Tarsus, today at the National Museum in Athens; inv. no. 1158: PM I, pl. 64, fig. 395.

${ }^{3}$ Alföldi-Rosenbaum 1971, pl. L1-2; and Russell 1973, 327, no. 5, fig. 5.

${ }^{4}$ Barker 1853; and Fleischer 1984.

${ }^{5}$ Çalık 1997, 103f. A list of statues from the Museum of Tarsus: Op. cit., nos. 7, 8, 17, 23, 39-41, 57-58, 67$68,73,81,83-84,89-90,94,103-104,121,137,149,150,159$ and 211 . The only stele in her work is no. 253 at the Museum of Silifke. 
the complete collection of steles in Cilicia both in iconographic and epigraphic aspects and create a systematic corpus, based on their material, inscriptions, subject, iconography, typology, dimensions, layout, proportions, techniques and quality of workmanship. Our intention is to present unpublished steles and to revise formerly published steles. A base has already been established with the publication of steles at the Museum of Hatay where a large number of pieces are kept. ${ }^{6}$ Recently a catalogue of the sculptures at the Museum of Silifke has been prepared by Serra Durugönül which is a first step towards a systematic cataloguing of the sculptural objects in Cilicia. ${ }^{7}$ Steles in the museums of Alanya and Mersin are being edited at the present. ${ }^{8}$

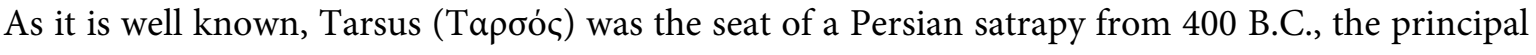
town of Hellenistic Cilicia, the capital of the Roman province of Cilicia and the birth place of Paul the Apostle. Located on the mouth of the river Cydnus (today Berdan/Tarsus Çayı) the city was situated on the junction of land and sea routes connecting the Cilicia Pedias, Central Anatolia and the eastern Mediterranean. The countryside around Tarsus provided an excellent farmland. ${ }^{9}$ The ancient city's core was Gözlükule, a höyük site located in the southwest edge of the modern city. The Hellenistic and Roman city of Tarsus is located just north of Gözlükule; at the same time Gözlükule was in use as a residential area, a necropolis ${ }^{10}$ and a workshop place for the local coroplastic production as well as other manufacturers. Under Seleucid control Tarsus was largely influenced by Greek language and culture and it became more and more Hellenized. In 67 B.C. Pompey, after crushing the Cilician pirates, subjected Tarsus to Rome, and it became capital of the Roman province of Cilicia. In the Roman period, the city was an important intellectual centre and when the province of Cilicia was divided, Tarsus remained the civil and religious metropolis of Cilicia Prima. The city remained largely pagan up to the time of Julian the Apostate (A.D. 361-363) who reportedly planned to make it his capital. Since the $18^{\text {th }}$ cent. Tarsus was an attractive place for researchers: the French Orientalist Victor Langlois made an expedition to Tarsus and Cilicia in 1852-1853 in order to excavate at Gözlükule, where he found numerous terracotta figurines brought subsequently to the Louvre. So far the most important excavations in Tarsus were those run by U.S. American scholars at Gözlükule before and after the World War II: Hetty Goldman has directed an excavation at Gözlükule in 19371948 and published the results after 1950. Today Gözlükule is being re-excavated by a team from Boğaziçi University, but very few finds of Hellenistic and Roman periods are published so far. Between the 1950s and 2010s only rescue excavations and coincidental finds are known from Tarsus. During the construction of the Palace of Justice of Tarsus in 1943-1944 several mosaic panels of the $3^{\text {rd }}-4^{\text {th }}$ cent. A.D. have been found, but no steles. Also during the rescue excavations, cleaning and restoration of the so-called "St. Paul's Well", a monumental tomb at "Köylü Garaj1" (Domestic Coach Station), ${ }^{11}$ the so-called "Mausoleum of the Prophet Daniel" and the Roman Bath (Makam) some finds were collected, but no steles. Two important excavations in Tarsus did not provide any stele: the Roman Temple at Donuktaş was excavated by a Turkish team headed by Nezahat Baydur between

\footnotetext{
${ }^{6}$ Lafl1 - Meischner 2008; and Lafl1 - Christof 2014. Also Güven 2015.

${ }^{7}$ Durugönül 2013.

${ }^{8}$ Laflı - Christof in progress.

${ }^{9}$ Welles 1962, 45-46.

${ }^{10}$ Goldman 1950, 19-24, figs. 64-80.

${ }^{11}$ Yurtseven 2008.
} 
1982 and 1992. ${ }^{12}$ This temple was supposed to be the largest Roman temple of the ancient world and today there is a survey project in its fundaments. ${ }^{13} \mathrm{~A}$ second and less known one is the excavation of a Roman road and magazins at Cumhuriyet Meydanı (Republican Square), directed by Kâmil Levent Zoroğlu in 1990s. ${ }^{14}$ These rescue excavations brought to light various finds of Late Antiquity of Tarsus. In the course of epigraphic surveys of Mustafa Hamdi Sayar in Cilicia not much about the steles of Tarsus has been reported.

The necropoleis of Greek and Roman Tarsus are not known in detail ${ }^{15}$ and most of the burial evidence consists of chance finds. Two recently published monumental reliefs of Men and of a Silen from Tarsus are coming apparently from a necropolis area in Tarsus. ${ }^{16}$ Some more tombs are known from the "Şelale" (waterfall) area, but no steles in situ. Other finds, such as the tomb at Köylü Garajı etc. are singular.

In 1971 the Museum of Tarsus was founded in a building which was formerly an educational institute (madrasa), built by Kubad Paşa, a Ramadanid ruler during the $16^{\text {th }}$ cent. Prior to 1971 finds from Tarsus were brought to Louvre, the British Museum, the Archaeological Museums of Istanbul and Regional Museum of Adana. In 1999 the museum was moved to its present building which is included in the city's social center known as "Cultural Complex of the $75^{\text {th }}$ Anniversary of the Turkish Republic". A new building for the Museum of Tarsus is now under construction.

Steles kept at the Museum of Tarsus were documented by Ergün Laflı and Emel Torum in 2013 with the permission of the Museum of Tarsus. The provenance of the objects is mostly unknown, with the exceptions of three steles from Antioch-on-the-Orontes and Seleucia Pieria in Hatay which have been either donated to the Museum of Tarsus or brought by local sellers from the area of Hatay. No stele is known from any excavations in or around Tarsus; all the finds in the museum come from nonarchaeological contexts: they were brought to the museum and purchased from local salesmen; therefore their provenance could be anywhere in Asia Minor. Also the excavations in other parts of Cilicia do not provide any help about the use of steles in Greek and Roman Cilicia. In this article the steles of Tarsian origin stored elsewhere (for instance at the collections of the Archaeological Museums of Istanbul) are excluded. The total number of steles is 10; most of them are marble with the exception of no. 1 that is of limestone. Five of the grave steles bear a Greek inscription. Only four of them belong to the Hellenistic period (nos. 1-4); the rest date from the $2^{\text {nd }}$ and $3^{\text {rd }}$ cent. A.D. Only two of them are votive steles (nos. 1 and 9) and an ossuary fragment (no. 10); the rest are grave steles. So far only no. 3 is known in epigraphic publications; the rest is unpublished. Seven steles are exhibited in the sculpture hall of the museum; the remaining three are in the depot.

\footnotetext{
12 Baydur - Seçkin 2001: No stele was found in these excavations.

${ }^{13}$ The temple is now being re-surveyed by Winfried Held (Marburg).

${ }^{14}$ Zoroğlu 2001.

${ }^{15}$ For a list of the ruins at Tarsus, $c f$. Hild - Hellenkemper 1990, 428-439. The authors consider that Hellenistic and Roman Tarsus is almost entirely demolished: op. cit., 433-434.

${ }^{16}$ Durukan - Durugönül 2009, $199 f$.
} 


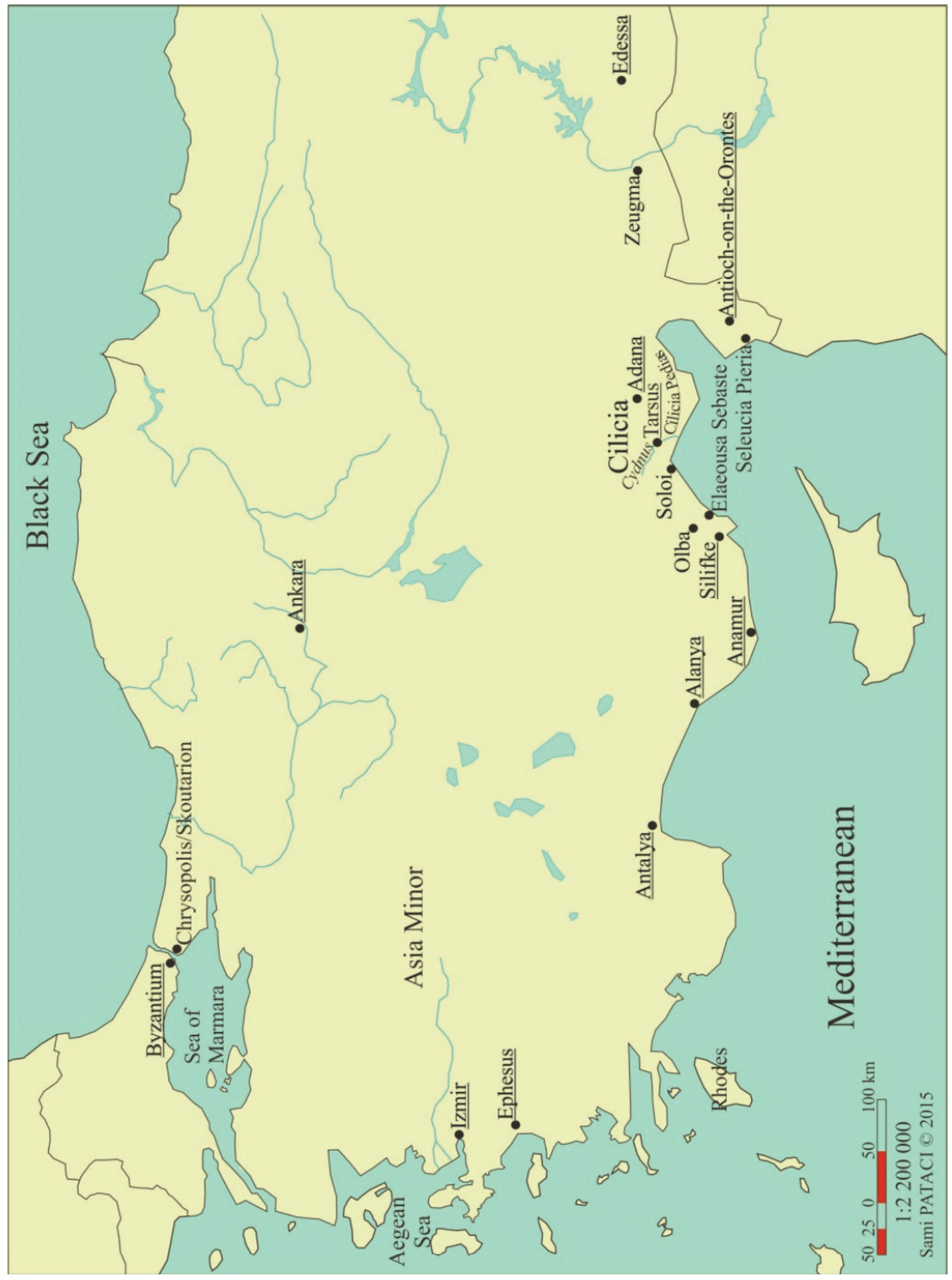

Map 1) Map of Tarsus, Cilicia and other quoted places in the text. Underlined places indicate cities with local museums (S. Pataci, 2015). 


\section{Catalogue}

\section{No. 1. A limestone votive stele with double figures (fig. 1)}

Inv. no.: 984-7-9.

Material: Limestone with a very porous surface.

State of preservation: Chips from the edges of pediment and bottom. Surface worn, weathered and yellowed.

Provenance: Acquisition; perhaps from Rough Cilicia, i.e. the surroundings of Silifke.

Measurements: H. $32 \mathrm{~cm}$; w. $20 \mathrm{~cm}$.

Description: This remarkably shallow relief block shows two roughly worked figures, framed by columns or pilasters in flat relief. The two figures depicted are two nearly identical female divinities in a high girded, long chiton, with a helmet, a shield and a lance. ${ }^{17}$ Their appearance reminds the sphere of war and can be interpreted as double Athenas. The pediment seems to be decorated with a moon

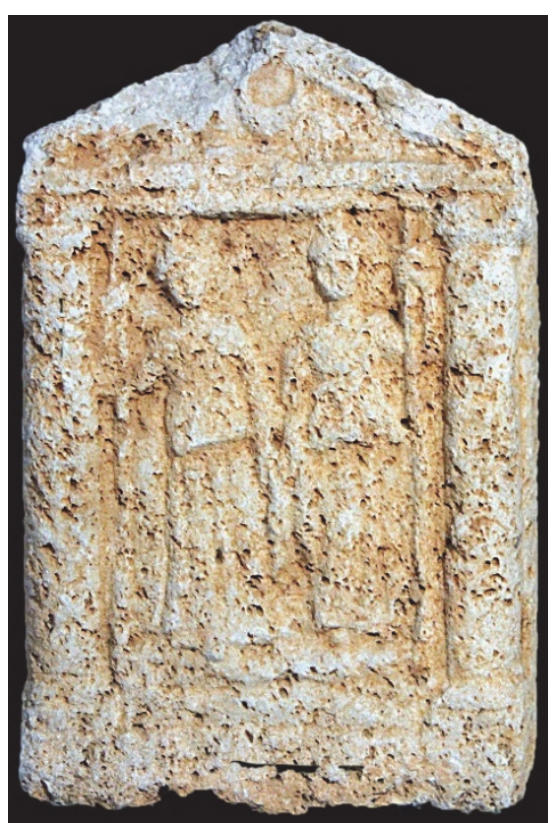

Fig. 1 crescent. ${ }^{18}$ Over a long span of time double depictions of goddesses are common in Asia Minor for Demeter, Athena, Artemis and Cybele and according to Fahri Işık and other scholars they originate in an older Anatolian Mother-Goddess. ${ }^{19}$ In the Museum of Silifke two stone monuments of similar dimensions are stored which share the standing figures in weapons. ${ }^{20}$ They have been found in Olba (Uzuncaburç) and have been dated to the $3^{\text {rd }}$ cent. B.C. They can be interpreted neither as male warriors nor as grave monuments of soldiers, because they wear female dresses. An interpretation as double goddesses, probably double Athenas, and a function as votives should be preferred.

The figures exhibit a rather local and simplified workmanship. The drapery motif is comparable particularly to rock-cut reliefs in Cilicia Tracheia as the composition and treatment are strikingly similar.

Dating: Late $3^{\text {rd }}$-early $2^{\text {nd }}$ cent. B.C.

${ }^{17}$ For double representations of a female goddess: Hadzisteliou Price 1971; and in Asia Minor: Fleischer 1984, 98-101; Işık 2013.

${ }^{18}$ Crescents are common attributes on funerary steles from Cilicia Pedias: Çalık 1997, 90.

${ }^{19}$ Cf. Işı1k 2013; Robert 1960, 178 f.; Helck 1971, 28 f.; Haas 1981, 5-21; Robert 1983, 559, note 30a; Lehmann 1988; Simon 1995 (not convincing); and Becker et al. 2012, 30-31 (divine dyads).

${ }^{20}$ Durugönül 2013, 109-110, nos. 76-77 (with figs.). 


\section{No. 2. A grave stele with a banquet scene (fig. 2)}

Inv. no.: 984-7-112.

Material: Fine grained marble.

State of preservation: The middle edge, right upper corner as well as right corner of the stele are missing. The heads of all three figures are seriously damaged. Surface has some encrustation on its lower and uppermost parts.

Provenance: Acquisition (?). Measurements: H. $45 \mathrm{~cm}$; w. 55,5 cm.

Description: The relief is framed by two simple pilasters, owns an architrave and shows a row of akroteria at the front. Three figures are spread in front of the empty background. On

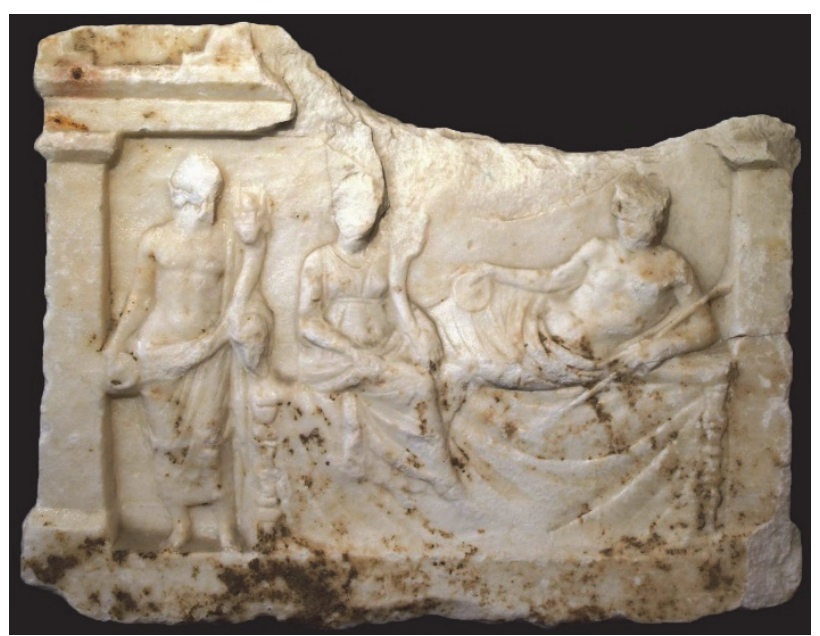

Fig. 2 the right side there is a male reclining hero and a seated woman, while the left side is taken place by a naked male figure with hip-mantle, carrying a full cornucopia in one arm and a phiale, in the other. The seated woman, dressed in a high girded chiton, carries a full cornucopia in her left hand too. Her feet are far from touching the ground. The kline is almost entirely covered by cloth, but on the edges both of its feet are visible. Both male figures are displayed with naked upper body. It seems remarkable that all three persons are holding a round phiale. The heads are preserved only in outlines. This scene used in heroisations of the deceased in Hellenistic and Roman Syria was also very popular in Cilicia. $^{21}$

Dating: The pictorial style of the relief and the comparison with other steles lead to a dating to the $1^{\text {st }}$ half of the $2^{\text {nd }}$ cent. B.C. ${ }^{22}$

\section{No. 3. Votive stele of a goddess, secondarily reused as a grave naiskos dedicated to a mother with three children (figs. 3a-b)}

Inv. no.: 980-67-1.

Material: Fine grained marble with heavy grey veins.

State of Preservation: Right corner of the pediment as well as some chips are missing on the surface.

Provenance: It was found in Seleucia Pieria in Samandağ, acquired on 10/11/1972 and brought from the Museum of Hatay to Tarsus on 03/05/1980.

Measurements: H. $128 \mathrm{~cm}$; w. $43 \mathrm{~cm}$; h. o. ltr.: c. $1.5 \mathrm{~cm}$.

${ }^{21}$ On this scene in Hellenistic Asia Minor in general: Dentzer 1978, 69-71.

${ }^{22}$ The figures share the same concept of the body e. g. with the relief PM I, no. $1109 \mathrm{pl} .167$ (dated to the $1^{\text {st }}$ half of the $2^{\text {nd }}$ cent. B.C.). 


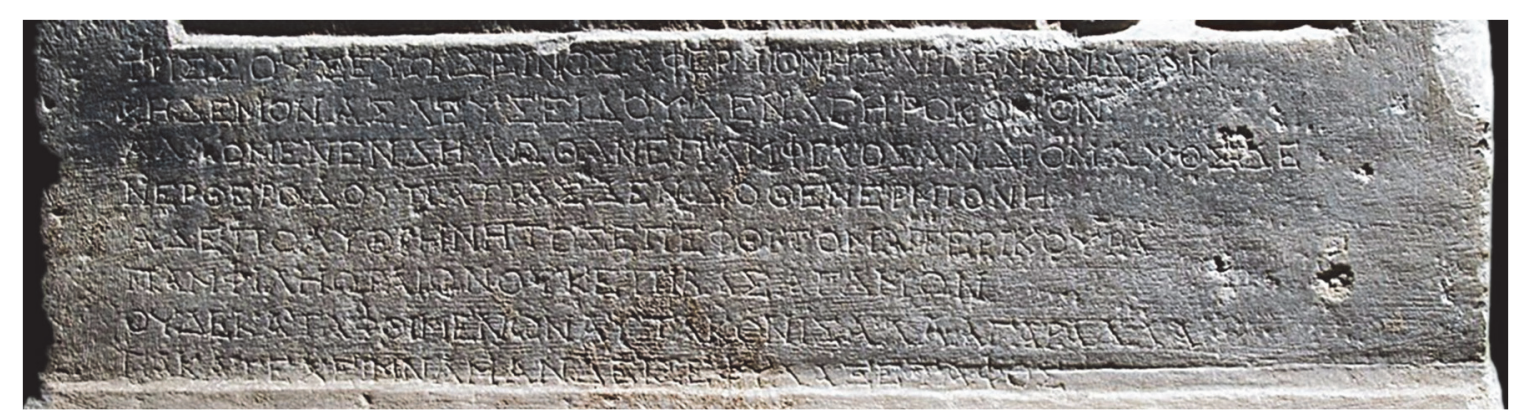

Fig. 3a

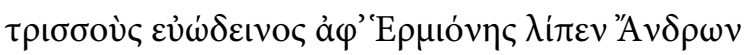

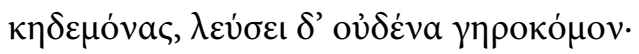

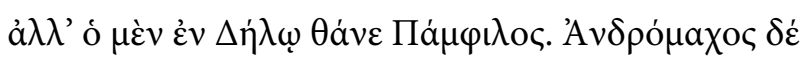

4

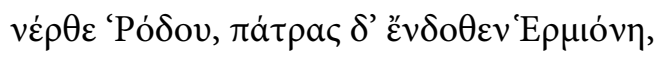

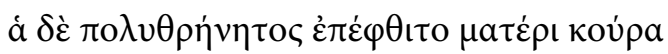

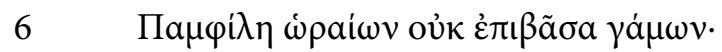

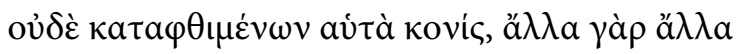

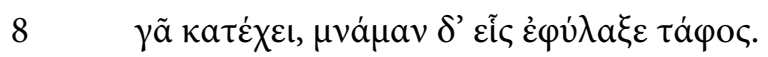

Three "guardians" were what Andron begot from fertile Hermione, but no one of them will take care of him in his old age. Pamphilos died in Delos; Andromachos lies under (the earth of) Rhodes, while Hermione (the wife) lies at home. The much mourned girl Pamphile died (soon) after (her) mother, without "enjoying" a beautiful wedding; and it is not the same earth that covers the deceased, but different soil preserves each of them; and a single grave preserves their memory.

Epigraphic Comments: The text is similar to Merkelbach - Stauber

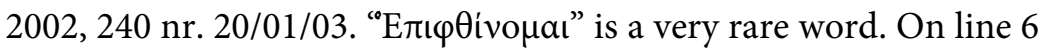

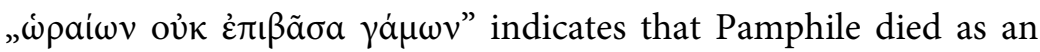
" $ڤ \omega \rho \rho \varsigma^{\prime}$ ", i.e. before she matured. For this subject $c f . e . g$. Lattimore 1942, 184-187 \$ 48; and Vérilhac 1978/1982. On line 7 „AYTA“ means „á aútà”. This stele serves both as a gravestone for Hermione and her daughter Pamphile as well as a memory of the late Pamphilos and Andromachos.

Description: High rectangular, pedimental stele with an unworked lower part for fixation. An arched relief field comprises the figural scene, under which a formerly published poetic Greek archaizing epitaph with specific formulae ${ }^{23}$ runs. The figures are arranged in front of the empty background in a way that a lot of free space remains

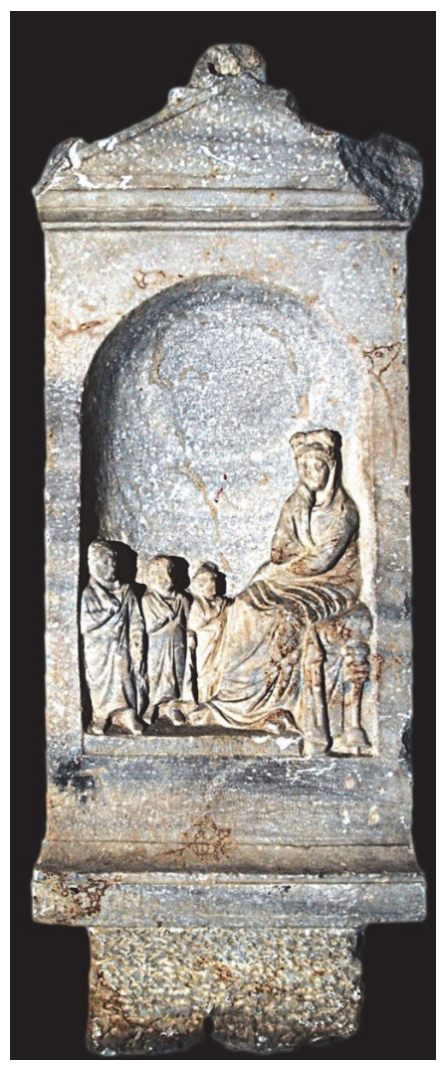

Fig. 3b

\footnotetext{
${ }^{23}$ Probably Aeolic or Doric; $c f$. Dickie 1994, 117f.: "Kaibel long ago remarked that inscriptions for ephebes are wont to speak in Doric. The practice is by no means confined to epitaphs for ephebes. Doric is found in grave-
} 
above them. On the right side there is a woman seated on a stool without backrest, turned towards three smaller scaled men approaching to her. The woman is given in a three quarter view; thus an excellent deep view effect is achieved. She puts one arm across the body and supports the other arm with the hand directed to her chin. Her hairstyle recalls Hellenistic Aphrodite types. Three figures, graded by size, are dressed in an himation with a sling and reach up in size to the knees of the woman. They are standing on the same pedestal, on which the woman rests her feet. Lots of chisel marks on the surface.

Comparanda: A parallel is known at the Museum of Hatay: Lafl1 - Meischner 2008, 156-157, no. 17 (a female holding a child on her lap).

Dating: According to Merkelbach - Stauber the inscription is from the $1^{\text {st }}$ cent. B.C.; iconographically, however, the stele should belong to the middle of the $2^{\text {nd }}$ cent. B.C. The visual narrative of the scene is that of a votive relief, ${ }^{24}$ showing a goddess and three worshippers. It is therefore highly probable that the inscription was carved secondarily below the relief, and the votive relief was transformed to a grave relief.

Bibliography: Dagron - Feissel 1987, 85, no. 41 and pl. 20; SEG 37, 1987, no. 1459; as well as Merkelbach - Stauber 2002, $240 \mathrm{nr} .20 / 01 / 03,245$, no. 20/03/06 (with a translation into German).

\section{No. 4. Lower part of a grave stele of a girl with a dog (fig. 4)}

Inv. no.: 07-2-1.

Material: Marble.

State of preservation: Its upper part was broken away in the middle. No. 4 is a lower fragment with some chips which is being stored in the depot.

Provenance: Donation in 2005.

Measurements: P. h. 41,5 cm; w. $40 \mathrm{~cm}$; h. o. ltr.: c. $2 \mathrm{~cm}$.

Inscription: Two lines under the figural scene.

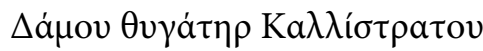

2

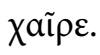

Damous, daughter of Kallistratos,

fare well!

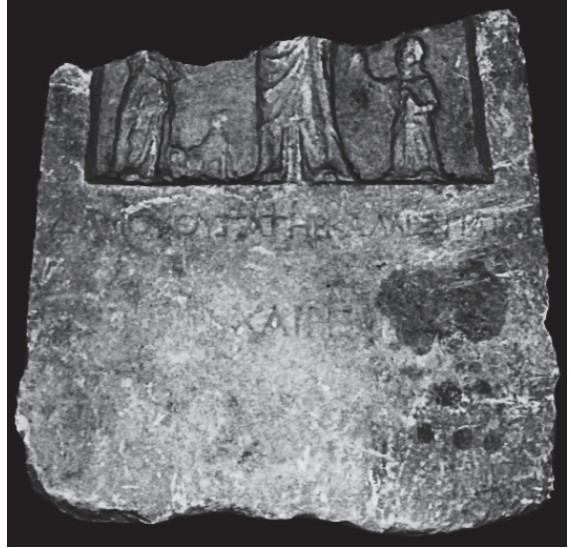

Fig. 4

inscriptions for children and young women. ... It may be that Doric was associated with the plangent tone of lamentation.”. Also Catling - Kanavou 2007, 107.

${ }^{24}$ Cf. several examples in Edelmann 1999. 
Epigraphic Comments: The name of the daughter is Damous; for this kind of names $c f$. Schulze Wissman 1934, 309 and 384 f., note 11: "Die Namen in -oṽ s sind die vulgären Fortsetzer der Nomina auf - $\omega$, durch analogische Neuschöpfung erwachsen aus den alten Akk. auf -oṽv und zwar erwachsen auf ionischem Sprachgebiete. Fast immer stehen den Fem. auf -oṽc Mask. auf -ã c zur Seite”. Also Robert 1963, 381 f.; as well as Petzl 1982, 3 no. 4 (with further references). In this inscription the nominative $\theta v \gamma \dot{\alpha} \tau \eta \rho$ was used instead of the vocative $\theta \dot{v} \gamma \alpha \tau \varepsilon \rho$. For using the nominative instead of the vocative, see Svennung 1958 and Blass - Debrunner - Rehkopf 1979, 121f. § 147.

Description: The stele shows three female figures, of which just the girl on the right side is entirely complete. This girl is approaching the woman in the centre, who is given in a bigger scale, and is offering her something in the outstretched right hand, perhaps a bunch of grapes (?), while holding a bird in the other hand close to the body. On the left side a servant or girl is depicted and between her and the bigger scale central woman there is a little dog directed and looking upwards to the main female figure. A dog usually accompanies a dead girl, not an adult. ${ }^{25}$

Dating: $1^{\text {st }}$ cent. B.C

\section{No. 5. A grave slab with a reclining woman (fig. 5)}

Inv. no.: 980-6-1.

Material: Fine grained marble.

State of preservation: The slab is vertically broken through middle with some chips. There is also a horizontal crack. Surface has some encrustations and is yellowed.

Provenance: Acquisition on 03/05/1980.

Measurements: H. 128 cm; w. 43 cm; h. o. ltr.: c. 2 cm.

Inscription: One line under the figural scene.

$\Delta o \mu v[i] v \alpha \cdot a ̈ \lambda v \pi \varepsilon \chi \alpha i ̃ \rho \varepsilon$.

Domnina, free of worry, fare well!

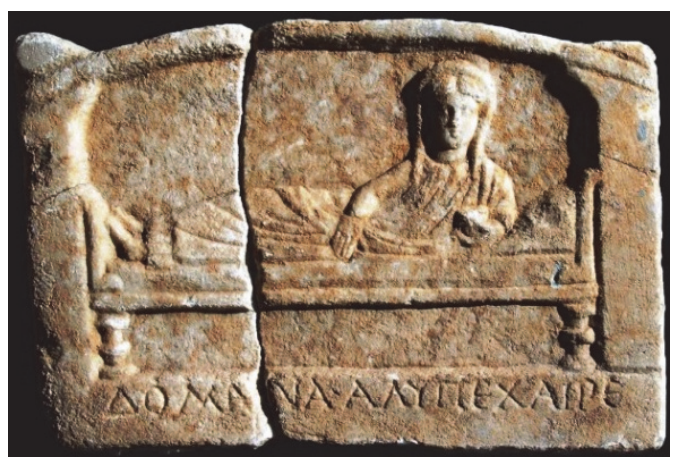

Fig. 5

Epigraphic Comments: The Latin personal name of Domnina (sometimes appears as " $\Delta \mathrm{o} \mu \nu \varepsilon \tilde{v} v$ ") is often encountered especially in the epigraphical or historical sources of northern Syria as well as Cilicia; cf. Gatier 1988, 228, inscription no. 5 (from Nisibis, today in Al-Hasakah; end of $2^{\text {nd }}$-early $3^{\text {rd }}$ cent. A.D.); and Rey-Coquais 1998, 199. Domnina can also refer to several Christian female saints in

\footnotetext{
${ }^{25}$ Dogs depicted on grave reliefs: Schmidt 1991, figs. 1-3. Very similar for the simple framing of the grave stone and the figural inventory: PM 1, no. 392, pl. 64; cf. also PM 1, no. 397, pl. 65. The main person of these grave steles is always a girl.
} 
the same area: Domnina of Anazarbus (died on A.D. 286), Domnina of Antioch on the Orontes (died on A.D. 310) and Domnina of Kyra near Antioch (died on c. A.D. 450-460) are venerated as Christian martyrs of Late Antiquity. A Domnina of around A.D. 166 in western Asia Minor was a doctor: Reinach 1933, 313. A further doctor with the name Domnina is known in Latin epigraphic sources: Flemming 2007, 259 and note 11. Latin and Semitic names are not rare on Antiocheian steles: Lafl Christof 2014, 169-170, no. 21 and note 14 (Rufina). A $\Delta$ opveĩva is known from a funerary stele from Elaeousa-Sebaste (today at the Museum of Anamur, inv. no. 2.938.90), dated to the $3^{\text {rd }}-4^{\text {th }}$ cent. A.D.: cf. Lafl1 - Christof 2015, 195-196, no. 18.

For "ä $\lambda v \pi \varepsilon$ " $c f$. Tod 1951, $186 \mathrm{f}$. The word bears two distinct meanings, which we may term active and passive, (a) causing no grief (or pain), and (b) suffering no grief (or pain). In prose epitaphs, however, the word is to be taken in its active sense.

Description: The slab shows a woman, faced frontally, stretched out on a bed-couch, a kline. She wears a long undergarment and a mantle which is pulled over her head as a veil. Her left hand is holding a drinking cup. The figure's head is too large in relation to the body, thus underlining the importance of the head. The slab is framed by side bars, has a curved lintel as upper closure, and disposes of two lateral akroteria. The kline which fits exactly into the space defined by the side bars and was carefully detailed, has a high head and foot end. This foot shows three cylindrical elements on each leg, as it might have corresponded to the real wooden furniture at the same time. In comparison to the bulk of banquet reliefs and reclining heroes reclining heroines are seldom in Hellenistic and Roman Asia Minor and this stele is in the most reduced form which shows just the essential figure of the reclining banqueter. The form of the slab and the overall composition show strong similarities with the stele of Epicharis from Chrysopolis/Skoutarion (Üsküdar) at the Archaeological Museums of Istanbul ${ }^{26}$ and several steles of the Roman Imperial period from Antioch-on-the-Orontes. ${ }^{27}$

Dating: Late $2^{\text {nd }}-3^{\text {rd }}$ cent. A.D.

\section{No. 6. A stele of a man with a bundled scroll (fig. 6)}

Inv. no.: 984-7-115.

Material: Marble.

State of preservation: Horizontally broken through lower part. Two joining fragments. Left anta of the naiskos' façade not preserved. Worn face. Stored in the depot.

Provenance: Acquisition.

Measurements: H. 34 cm; w. 25 cm; h. o. ltr.: c. 2 cm.

Inscription: One line under the figure. Typical phrases of the commemoration. Unfortunately, the personal name should be in the lost part.

${ }^{26}$ Cremer 1992, pl. 29, fig. on the upper right side (Archaeological Museums of Istanbul, inv. no. 5664).

${ }^{27}$ Cf. Kondoleon 2000, 140 no. 29 (with fig.); evidently later in date: Lafl1 - Meischner 2008, 165-166, no. 31; and Lafl - Christof 2014, 170-172, 181 figs. 22-25. 


$$
\begin{aligned}
& \text { [- - ] } \alpha^{\prime} \lambda v \pi \varepsilon \chi \alpha \tilde{\rho} \rho \varepsilon . \\
& \text { [- - ] free of worry, fare well! }
\end{aligned}
$$

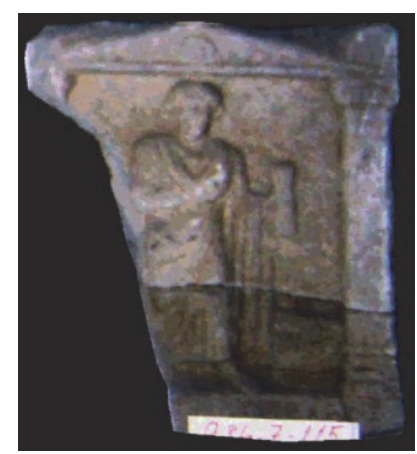

Fig. 6

Description: This stele with a flat pediment preserves a draped male figure in frontal view, processing to the right, holding a bundled scroll in front of him and thus representing himself as an educated person. ${ }^{28}$ The shoulders and head are parallel to the relief ground, but the feet faced three-quarters proper left. The figure wore a typical himation.

Dating: Late $2^{\text {nd }}-3^{\text {rd }}$ cent. A.D. based on type and style.

\section{No. 7. A banquet stele with the presentation of a wreath (fig. 7)}

Inv. no.: 07-2-2.

Material: Limestone.

State of preservation: Right corner missing. Surface, especially faces, worn, yellowed and weathered. Stored in the depot.

Provenance: Donation in 2005; perhaps from the surroundings of Byzantium.

Measurements: P. h. 59 cm; w. 56 cm.

Description: Rosette with six petals in a circle at the summit of the pediment, lateral akroteria, a simple and plane phiale in the pediment: a reclining male figure on a bed couch with high upper and lower end, in a long garment, covering his whole body, gazing frontally, presenting a wreath and holding a drinking cup in the other hand. A veiled woman, perhaps in a protopudicitia type ${ }^{29}$ in three quarter view seated on the kline as well. From the left margin a female servant approaches, offering a rectangular box. In front of the bed couch there is a round table with three animal legs, supporting some drinking cups. All heads have a worn surface. Very characteristic in this relief is the rendering of the tight and linear crinkles and the clumsy proportions of the bodies, e.g. the very

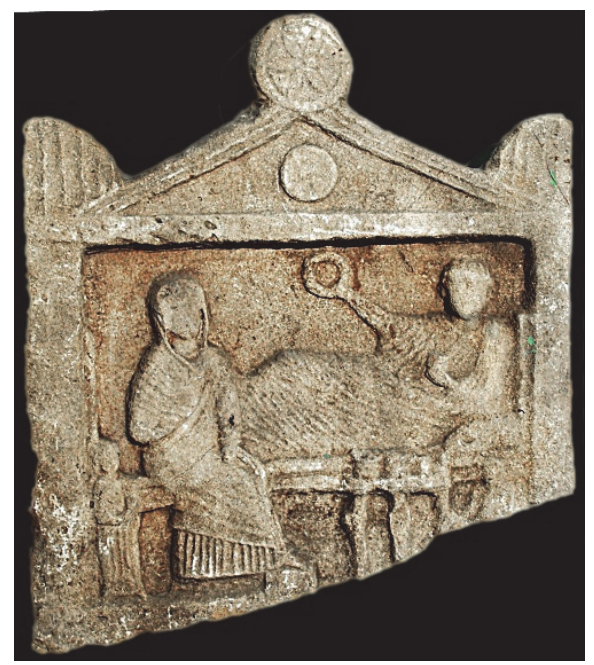

Fig. 7

${ }^{28}$ For the meaning of book scrolls and the eagerness of education on steles in Roman Asia Minor: Fabricius 1999, 248-254; and Marek 2003, 149-160 with figs.

${ }^{29}$ Cremer 1991, 87. 
short upper body of the reclining man. The decoration scheme is typical for grave steles in Byzantium. $^{30}$

Dating: End of the $2^{\text {nd }}$-beginning of the $3^{\text {rd }}$ cent. A.D.

\section{No. 8. A naiskos stele of a reclining hero and his servant (fig. 8)}

Inv. no.: 973-5-3.

Material: Marble with grey veins and calcium carbonate $(\mathrm{CaCO} 3)$.

State of Preservation: Faces worn. Edges missing some chips.

Provenance: Acquisition on 29/05/1973; it was brought from the surrounding of Hatay.

Measurements: H. $44 \mathrm{~cm}$; w. 35,5 cm; h. o. ltr.: c. 2 cm.

Inscription: Under the relief scene a Greek inscription with three lines is engraved.

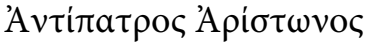

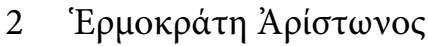

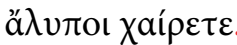

Antipatros, son of Ariston

Hermokrate, daughter of Ariston,

Free of worry, farewell!

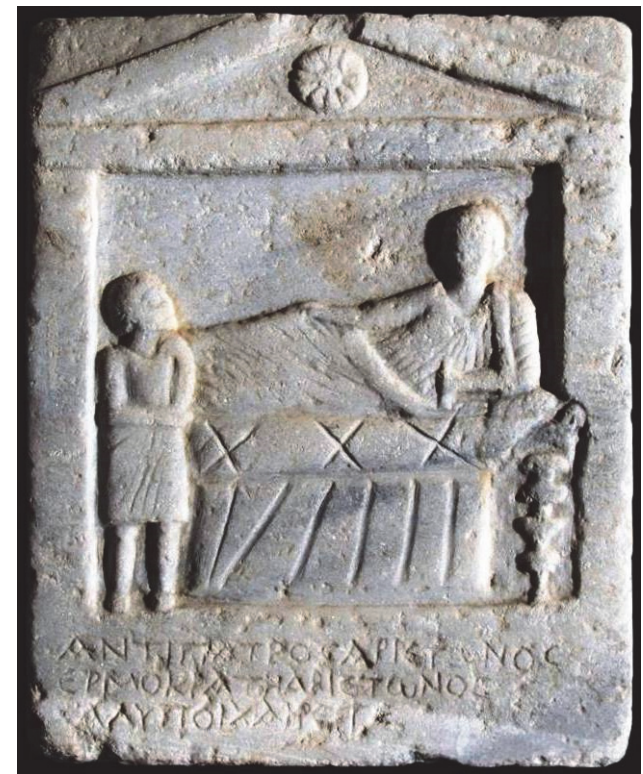

Fig. 8

Description: The rectangular stele has a simple frame and a simple pediment, decorated with a rosette. The reclining hero, dressed in a fine draped dress lies on a kline holding a tiny cup in one hand. On the left edge a servant figure in short dress with one arm crossed over the body, the other put to the chin, although represented frontally, looks up to the recumbent hero toward the left. ${ }^{31}$

The execution of the relief is characterized by many narrow lines for the folds of the dress. The thick mattress shows three engraved marks and the piece of cloth falling down from the kline is marked with coarse engraved ridges. Some chisel marks on the surface.

Dating: Middle of $3^{\text {rd }}$ cent. A.D.

${ }^{30}$ Sayar 1982, 292-293, pl. IX, nos. 3-4; Firatlı - Robert 1964, pls. 14-25; Karagöz 1984, p. 21, figs. 16-17; and Fabricius 1999, 236 ss. F70, pl. 22b; F78, pl. 23a; F67, pl. 24a.

${ }^{31}$ For the body language of slaves: Masséglia 2015, 196-204. 
Bibliography: In 2010 this piece has been analyzed archaeometrically without any precise result in the regards of its marble source: Demirkıran 2010, 52, sample no. 13.

\section{No. 9. An usual votive stele with abstractions (fig. 9)}

Inv. no.: 974-15-8.

Material: Phrygian (?) marble.

State of Preservation: Heads of three top figures missing. Chips on the yellowed surface.

Provenance: Acquisition on 18/07/1974; it was probably brought from the outside of Cilicia (Pisidia or Phrygia?).

Measurements: H. $31 \mathrm{~cm}$; w. $15 \mathrm{~cm}$.

Description: Apart from the unworked lower part for fixation, this votive stele consists of three decorated parts: three figures on the top, a portrait in the middle and four objects at the bottom. At the top, three separate statuettes of deities are presented, perhaps Leto (or Cybele?) in the middle who was the mother of the twin gods Apollon and Artemis that were placed in her long sides. Leto in the middle is depicted larger than the other figures. These headless figures are seated and dressed in a Greek peplos or chiton as the density as well as arrangement of the thick vertical drapery folds show. These emphasized broad and linear folds contribute a classical element to this unique votive stele. The middle part is being bordered by a possibly portrait bust of a female. Four objects at the bottom enrich the scenery: in the right upper corner a bucranium, at the middle a horizontal object with lopsided grooves and in the bottom part an unknown triangle object (a weight?) on the left and a mirror on the right. Bucrania and mirrors are typical symbols at the grave steles in Roman Asia Minor.

Dating: Late $2^{\text {nd }}$-early $3^{\text {rd }}$ cent. A.D.

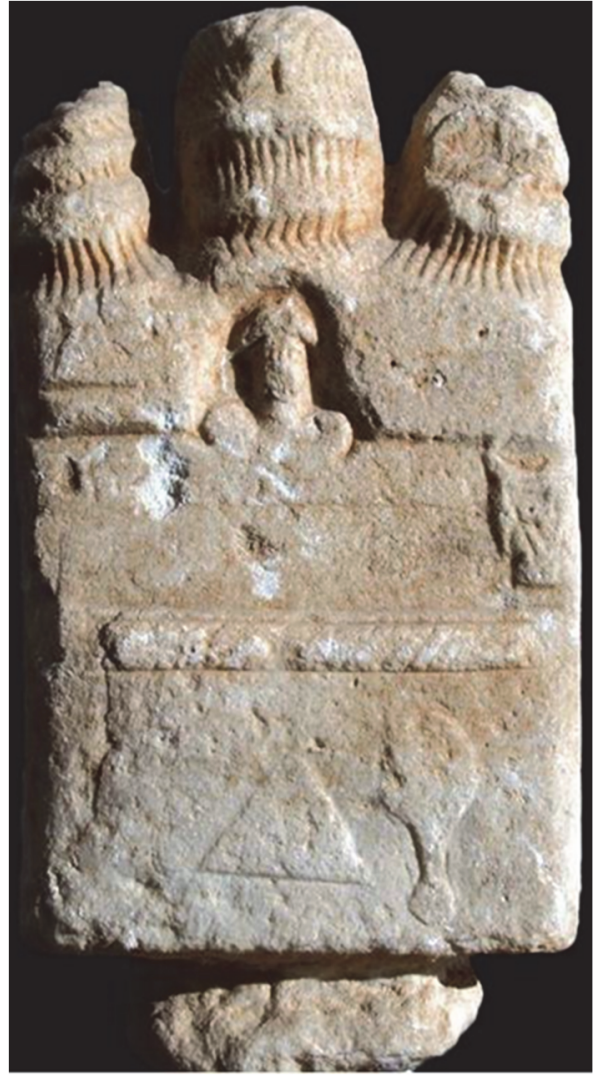

Fig. 9

No. 10. A fragment of an ossuary with a pair of confronting Erotes holding a bunch of grapes over a crater (fig. 10)

Inv. no.: 972-33-3.

Material: Fine grained marble.

State of preservation: Bottom of the panel through the level of Erotes' knees is completely missing. Surface heavily weathered, yellowed, with some encrustation. Chips on the surface. Heads of the Erotes were damaged.

Provenance: Acquisition on 10/11/1972; it was brought from the surroundings of Tarsus.

Measurements: P. h. 28,5 cm; w. $62 \mathrm{~cm}$. 
Description: This decorative marble slab has a rectangular shape, perhaps belonging to the longer edge, i.e. the primary viewing side, of an ossuary, a classical cinerary urn. It could also belong to a thin revetment plaque and displays a high quality marble as well as skill. As its surface was smoothed and polished, it was brought to a careful finish, providing a fine sheen which heightens the classical effect of the scene. The panel shows a pair of confronting Erotes beside a belly crater, facing each other and holding a bunch of grapes above it. The scenery with a sharp contrast was bordered by a horizontally projecting lip on the top. The Erotes were represented nude and chubby, with two sets of wings and cloaks that curve in opposite directions. Their heads are preserved only in outlines.

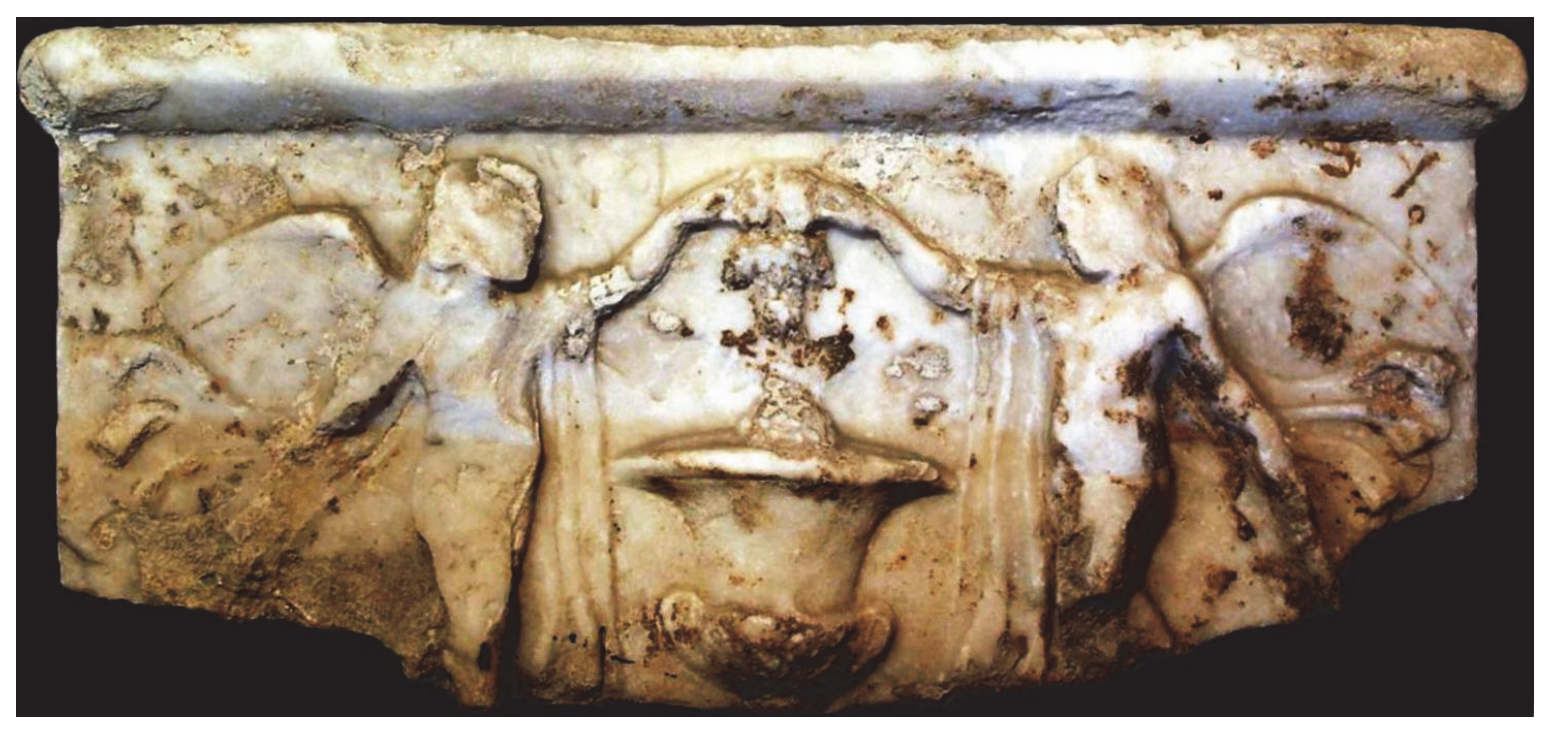

Fig. 10

Its Dionysiac content indicates its use as an ossuary. These scenes were popular in sarcophagi and they are associated with Dionysiac celebrations for the promise of a blissful afterlife or reminded of feasts held at tombs or imagery that adorned many homes and public spaces in Roman Asia Minor. On its right side a "XP" is visible (h. o. ltr. c. $3 \mathrm{~cm}$ ), perhaps in form of a christogram. Some further secondarily carved graffiti are visible on the surface, especially on the right side of Eros on the left, but not readable. They could be carved on the slab because of some later reworking. During the Hellenistic and Roman periods chthonic Eros was one of the most popular figures in the coroplastic finds at Gözlükule, at Donuktaş ${ }^{32}$ and in Tarsian terracotta productions. In Tarsus it is also common as freestanding figures. ${ }^{33}$

Dating: Beginning of $3^{\text {rd }}$ cent. A.D.

\section{Conclusions}

The Tarsus collection of Greek and Roman steles has a mixed character; nine unpublished steles originate from various parts of Asia Minor. Three of them are certainly from Antioch; the rest could be from anywhere. Both on Cyprus and in Syria the number of steles is significantly reduced which is a similar case for Cilicia. It seems that the tradition of grave steles was not very popular in Roman southern Asia Minor and eastern Mediterranean, except in large cities, such as Antioch-on-the-

\footnotetext{
32 Baydur - Seçkin 2001, pl. LXXIV, figs. 39-41.

${ }^{33}$ Çalık 1997, 63-64.
} 
Orontes, Zeugma or Edessa in the east. So far the only Greek Classical Attic grave steles with a confirmed context were found in Soloi in eastern Cilicia (today in the Museum of Adana); ${ }^{34}$ for the Hellenistic and Roman periods there is almost no known stele in any archaeological context of Cilicia. In future studies the marble sources of Tarsian steles should be determined archaeometrically. ${ }^{35}$

\section{Bibliography}

Alföldi-Rosenbaum 1971

E. Alföldi-Rosenbaum, Anamur Nekropolü/The Necropolis of Anemurium, Türk Tarih Kurumu Yayınları Seri 6, 12, Ankara 1971.

Barker 1853

W. B. Barker, Lares et Penates, or Cilicia and its Governors; Being a Short Historical Account of that Province from the Earliest Times to the Present Day, London 1853.

Baydur - Seçkin 2001

N. Baydur - N. Seçkin, Tarsus Donuktaş Kazı Raporu [Tarih Arkeoloji Sanat ve Kültür Mirasını Koruma Vakfı Yayınları 6/Kazı ve Araştırma Raporları Serisi 3], Istanbul 2001.

Becker et al. 2012

N. Becker - O. Dietrich - Th. Götzelt - Ç. Köksal-Schmidt - J. Notroff - K. Schmidt, Materialien zur Deutung der zentralen Pfeilerpaare des Göbekli Tepe und weiterer Orte des obermesopotamischen Frühneolithikums, ZOrA 5, 2012, 14-43.

Blass - Debrunner - Rehkopf 1979

F. Blass - A. Debrunner - F. Rehkopf, Grammatik des neutestamentlichen Griechisch, Göttingen ${ }^{15} 1979,121$ f. $₫ 147$.

Catling - Kanavou 2007

R. W. V. Catling - N. Kanavou, The Gravestone of Meniketes Son of Menestheus: "IPrusa" 1028 and 1054, ZPE 163, 2007, 103-117.

Cremer 1991

M. Cremer, Hellenistisch-römische Grabstelen im nordwestlichen Kleinasien I. Mysien [Asia Minor Studien 4, 1], Bonn 1991.

Cremer 1992

M. Cremer, Hellenistisch-römische Grabstelen im nordwestlichen Kleinasien II. Bithynien [Asia Minor Studien 4, 2], Bonn 1992.

Çalık 1997

A. Çalık, Roman Imperial Sculpture from Cilicia [Unpublished Doctoral Thesis; King's College, London], London 1997; available at https://kclpure.kcl.ac.uk/portal/en/theses/roman-imperialsculpture-from-cilicia(52fdf4d0-393f-42f3-8373-470393fac704). html; accessed on 20 May 2015.

Dagron - Feissel 1987

G. Dagron - D. Feissel, Inscriptions de Cilicie [Travaux et mémoires du centre de recherche d'histoire et civilisation de Byzance, Collège de France, Monographies 4], Paris 1987.

Demirkıran 2010

Ş. Demirkıran, Kilikya Bölgesi'nden Seçilmiş Antik Mermer Eserlerin Kökeninin Saptanması [Unpublished Master of Arts Thesis; Çukurova Üniversitesi, Fen Bilimleri Enstitüsü], Adana 2010; available at http://library.cu.edu.tr/tezler/8138.pdf; accessed on 20 May 2015.

\footnotetext{
${ }^{34}$ Von Gladis 1973-1974 = Merkelbach - Stauber 2002, p. 207, cat. 19/11/01.

${ }^{35}$ On the marble sources of Tarsian sculptures: Çalık 1997, 103.
} 
Dentzer 1978

Dickie 1994

Durugönül 2013

Durukan - Durugönül 2008

Edelmann 1999

Fabricius 1999

Firatl1 - Robert 1964

Fleischer 1984

Flemming 2007

Gathier 1988

Goldman 1950

Güven 2015

Haas 1981

Hadzisteliou Price 1971

Helck 1971

Hild - Hellenkemper 1990

Işık 2013

Karagöz 1984
J.-M. Dentzer, Reliefs au banquet dans la moitié orientale de l'Empire romain: iconographie hellénistique et traditions locales, Revue archéologique 1, 1978, 63-82.

M. W. Dickie, An Epitaph from Stratonikeia in Caria, ZPE 100, 1994, 109-118.

S. Durugönül (ed.), Silifke Müzesi Taş Eserler Kataloğu: Heykeltıraşlık ve Mimari Plastik Eserler, Istanbul 2013.

M. Durukan - S. Durugönül, A Relief of the God Men from Tarsus, JdI 123, 2008, 199-213.

M. Edelmann, Menschen auf griechischen Weihreliefs [Quellen und Forschungen zur antiken Welt 33], Munich 1999.

J. Fabricius, Die hellenistischen Totenmahlreliefs: Grabrepräsentation und Wertvorstellungen in ostgriechischen Städten [Studien zur antiken Stadt vol. 39], Munich 1999.

N. Firatl1 - L. Robert, Les stèles funéraires de Byzance gréco-romaine, avec l'édition et l'index commenté des épitaphes [Bibliothèque archéologique et historique de l'Institut français d'archéologie d'Istanbul 15], Paris 1964.

R. Fleischer, Reisenotizen aus Kilikien, AA 1984, 85-104.

R. Flemming, Women, Writing and Medicine in the Classical World, ClQ New Series 57/1, May 2007, 257-279.

P.-L. Gathier, Inscriptions latines et reliefs du Nord de la Syrie, Syria 65, 1/2, 1988, 217-229.

H. Goldman, Buildings and Habitation Levels, in: H. Goldman (ed.), Excavations at Gözlü Kule, Tarsus. Vol. I: The Hellenistic and Roman Periods, Princeton, NJ 1950, 5-28 and figs. 1-86.

E. Güven, Antiocheia Mezar Stelleri, Belleten 2015 (in print).

V. Haas, Nordsyrische und kleinasiatische Doppelgottheiten im 2. Jt., Wiener Zeitschrift für Kunde des Morgenlandes 73, 1981, 5-21.

T. Hadzisteliou Price, Double and Multiple Representations in Greek Art and Religious Thought, JHS 91, 1971, 48-69.

W. Helck, Betrachtungen zur großen Göttin und den ihr verbundenen Gottheiten [Religion und Kultur der alten Mittelmeerwelt in Parallelforschungen 2 ], Munich/Vienna 1971.

F. Hild - H. Hellenkemper, Kilikien und Isaurien, Tabula Imperii Byzantini 5 [DenkschrWien 215], Vienna 1990.

F. Işık, Zur anatolischen Demeter, in: O. Bingöl - G. Kökdemir (eds.), Orhan Bingöl'e 67. Yaş Armağanı / A Festschrift for Orhan Bingöl on the Occasion of his $67^{\text {th }}$ Birthday, Ankara 2013, 207-235.

Ș. Karagöz, Anadolu'dan Mezar Stelleri, Arkaik-Greko, Pers-Hellenistik-Roma, Bizans Çağları / Anatolian Steles: Archaic-Greek/Persian-Hellenistic-Roman, Byzantium Periods [Arkeoloji ve Sanat 
Kondoleon 2000

Lafl1 - Christof 2014

Lafl1 - Christof 2015

Lafl1 - Christof in progress

Laflı - Meischner 2008

Lattimore 1942

Lehmann 1988

Marek 2003

Masséglia 2015

Merkelbach - Stauber 2002

Petzl 1982

PM 1-2

Reinach 1932
Yayınları, Müze, Sergi ve Koleksiyon Katalogları Dizisi 3], Istanbul 1984.

C. Kondoleon (ed.), Antioch: The Lost Ancient City, [published on the occasion of the Exhibition "Antioch - the Lost Ancient City", Worcester Art Museum, Worcester, Massachusetts, October 7, 2000 - February 4, 2001, the Cleveland Museum of Art, Cleveland, Ohio, March 18 - June 3, 2001, The Baltimore Museum of Art, Baltimore, Maryland, September 16 - December 30, 2001], Princeton, NJ 2000.

E. Lafl1 - E. Christof, New Hellenistic and Roman Grave Reliefs from Antioch, in: A. Özfırat - Ç. Uygun (eds.), Uluslararası Çağlar Boyunca Hatay ve Çevresi Arkeolojisi Sempozyumu Bildirileri / The Proceedings of the International Symposium on the Archeology of Hatay and its Vicinity through the Ages, 21-24 May 2013 Antakya [Mustafa Kemal Üniversitesi Yayınları No. 52], Hatay 2014, 161-181.

E. Lafl - E. Christof, Römische Skulpturen im Museum von Anamur in Kilikien, in: S. Montel (ed.), La sculpture gréco-romaine en Asie Mineure (Besançon, octobre 2014), Dialogues d'histoire ancienne, Institut des sciences et techniques de l'Antiquité, Besançon 2015, 177-206.

E. Laflı - E. Christof, Classical, Hellenistic, Roman and Early Byzantine Steles in the Museums of Alanya and Mersin in southern Anatolia, in progress for 2016.

E. Lafl1 - J. Meischner, Hellenistische und römische Grabstelen im Archäologischen Museum von Hatay in Antakya, ÖJh 77, 2008, 145-183.

R. Lattimore, Themes in Greek and Latin Epitaphs [Illinois Studies in Language and Literature V. 28, Nos. 1-2], Urbana, IL 1942.

P. Lehmann, „The Divine Twins“ or „the Twins ... Divine“?, in: M. A. Jazayery - M. Winter (eds.), Languages and Cultures. Studies in Honor of E. C. Polomé, Berlin/New York/Amsterdam 1988, 373-380.

C. Marek, Pontus et Bithynia, Die römischen Provinzen im Norden Kleinasiens, Mainz on the Rhine 2003.

J. Masséglia, Body Language in Hellenistic Art and Society [Oxford Studies in Ancient Culture \& Representation], Oxford 2015.

R. Merkelbach - J. Stauber, Steinepigramme aus dem griechischen Osten, Vol. 4: Die Südküste Kleinasiens, Syrien und Palaestina, Munich/Leipzig 2002.

G. Petzl (ed.), Die Inschriften von Smyrna I: Grabinschriften, postume Ehrungen, Grabepigramme [IK 23], Bonn 1982.

E. Pfuhl - H. Möbius, Die ostgriechischen Grabreliefs, vols. 1-2, Mainz 1977-1979.

S. Reinach, Médecins et femmes médecins, Revue archéologique, cinquième série, 35, 1932, 313. 
Rey-Coquais 1998

Russell 1973

Robert 1960

Robert 1963

Robert 1983

Sayar 1982

Schmidt 1991

Schulze - Wissman 1934

SEG

Simon 1995

Svennung 1958

Tod 1951

Vérilhac 1978/1982

Von Gladis 1973/1974

Welles 1962

Yurtseven 2008

Zoroğlu 2002
J.-P. Rey-Coquais, Deux stèles inscrites de Syrie du Nord, Syria 75, 1998, 193-200.

J. Russell, New Inscriptions from Anemurium, Phoenix 27/4, 1973, 319-327.

L. Robert, Monnaies et divinités d'Aspendos, Hellenica 11/12, Paris 1960, 177-188.

L. Robert, Noms indigènes dans l'Asie Mineure gréco-romaine [Bibliothèque archéologique et historique de l'Institut français d'archéologie d'Istanbul 13], Paris 1963.

L. Robert, Documents d'Asie Mineure XXVII: Reliefs votifs 11: Les Dioscures et Arès (légendes lacédémoniennes), BCH 107, 1983, 553 579.

M. H. Sayar, Beschriftete Grabstelen aus der Gegend von Byzantion im archäologischen Museum von Istanbul, ZPE 48, 1982, 291-295.

S. Schmidt, Hellenistische Grabreliefs. Typologische und chronologische Beobachtungen, Cologne/Vienna [a.o.] 1991.

W. Schulze - W. Wissman, Kleine Schriften von Wilhelm Schulze: Zum 70. Geburtstag am 15. Dezember 1933, Göttingen 1934.

Supplementum epigraphicum graecum.

E. Simon, Doppelgöttinnen in Anatolien, Griechenland und Rom, Eirene 31, 1995, 69-87.

J. Svennung, Anredeformen: Vergleichende Forschungen zur indirekten Anrede in der Dritten Person und zum Nominativ für den Vokativ, Uppsala 1958.

M. N. Tod, Laudatory Epithets in Greek Epitaphs, BSA 46, 1951 [= Papers Presented to Professor Alan Wace to Commemorate Fifty Years of Work in Archaeology], 182-190.

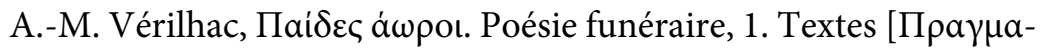

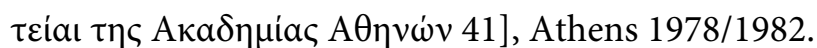

A. von Gladis, Ein Denkmal aus Soloi, IstMitt 23, 1973/1974, 175181.

C. B. Welles, Hellenistic Tarsus, Mélanges de l'Université Saint-Joseph 38, 1962, 41-75.

F. Yurtseven, Tarsus Köylü Garajı Mezarı Buluntuları, Ankara Üniversitesi, Dil ve Tarih-Coğrafya Fakültesi Eski Önyasa-Akdeniz Medeniyetleri Araştırma Enstitüsü, Anadolu 31.2006, 2008, 91-121.

L. Zoroğlu, Excavations at Antiocheia-on-the-Cydnus (Tarsus), in: T. Drew-Bear - M. Taşlialan - C. Thomas (eds.), Actes du Ier Congrès international sur Antioche de Pisidie [Collection archéologie et histoire de l'Antiquité, Université Lumière-Lyon 2], Lyon/Paris 2002, 417-422. 


\section{Kilikia Bölgesi’ndeki Tarsus Müzesi’nden Hellenistik ve Roma Dönemi Stelleri Özet}

Bu makalede tanıtılan on adet arkeolojik taş obje 2013 yllında Tarsus Müzesi'nde belgelenmiştir. Beş adet stel Yunanca yazıt içermektedir. Bu çalışmada stellerin hem ikonografik ve hem de epigrafik içeriği ele alınmaktadır. Amaç Kilikia müzelerindeki stellerin bir corpusunu oluşturmaktır.

Makalede incelenen yazıtların Türkçe çevirileri şöyledir:

No. 3: Andron'un doğurgan eşi Hermione'den (yaşlilığında) kendisine bakacak üç çocuğu oldu. Hiçbirisini ama yaşlllı̆̆ının bekçisi olarak göremeyecek. Pamphilos Delos'ta öldü; Andromakhos ise Rodos toprağının altında yatıyor. (Eşi) Hermione anavatanda; çok ağlayan küçücük kız Pamphile ise annesinin hemen ardından öldü evlilik çağına ulaşamadan. Rahmetlileri örten aynı toprak değil, aksine! Her birini ayrı toprak sakliyor. Fakat bir tek mezar anıtı gözetiyor anılarını!

No. 4: Ey Kallistratos'un kızı Damus! Elveda!

No. 5: Domnina: Kederlenme! Elveda!

No. 6: - - - : Kederlenme! Elveda!

No. 8: Ariston'un oğlu Antipatros, Ariston'un kızı Hermokrate: Kederlenmeyin! Sağlıcakla kalın!

Anahtar sözcükler: Kilikia; Tarsus; mezar stelleri; adak stelleri; mezar yazıtları; ostothekler; ölü ziyafeti sahnesi; Hellenistik Dönem; Roma İmparatorluk Çağı.

\section{Hellenistic and Roman Steles in the Museum of Tarsus in Cilicia}

\section{Abstract}

The following ten stone objects were documented in 2013 in the Museum of Tarsus. Five of them bear a Greek inscription. This study concerns both the iconography and the epigraphy of these steles. The intention is to create a corpus of the steles in Cilician museums.

Keywords: Cilicia; Tarsus; grave steles; votive steles; epitaphs; ossuaries; banquet scene; Hellenistic period; Roman Imperial period. 